\title{
Brian G. Rogers, Proust et Barbey d'Aurevilly. Le dessous des cartes
}

\section{Emanuele Kanceff}

\section{Q OpenEdition}

1 Journals

\section{Edizione digitale}

URL: https://journals.openedition.org/studifrancesi/39738

DOI: 10.4000/studifrancesi.39738

ISSN: 2421-5856

\section{Editore}

Rosenberg \& Sellier

\section{Edizione cartacea}

Data di pubblicazione: 1 décembre 2004

Paginazione: 407

ISSN: 0039-2944

\section{Notizia bibliografica digitale}

Emanuele Kanceff, «Brian G. Rogers, Proust et Barbey d'Aurevilly. Le dessous des cartes», Studi Francesi [Online], 143 (XLVIII | II) | 2004, online dal 30 novembre 2015, consultato il 19 mai 2021. URL: http:// journals.openedition.org/studifrancesi/39738; DOI: https://doi.org/10.4000/studifrancesi.39738

Questo documento è stato generato automaticamente il 19 mai 2021.

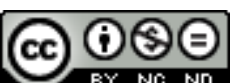

Studi Francesi è distribuita con Licenza Creative Commons Attribuzione - Non commerciale - Non opere derivate 4.0 Internazionale. 


\title{
Brian G. Rogers, Proust et Barbey d'Aurevilly. Le dessous des cartes
}

\author{
Emanuele Kanceff
}

\section{NOTIZIA}

BRIAN G. ROGERS, Proust et Barbey d'Aurevilly. Le dessous des cartes. Préface de Philippe BERTHIER, Paris, Honoré Champion éditeur, 2000 («Recherches peoustiennes», 1), pp. 300.

1 Barbey d'Aurevilly è presente fin da Les Plaisirs et les jours sia nella scrittura proustiana, sia nella sua meditazione critica. Uno dei punti di contatto più evidenti tra i due scrittori è certamente il tempo che si corporizza in certi paesaggi, certe case o chiese o castelli, certi oggetti, certi toponimi, certi profumi... Capitale è dunque la "sensazione" della storia; ma non meno importante la lettura, che l'A. ricostruisce nelle sue tappe essenziali; e altrettanto basilare la percezione del territorio e della razza, finemente analizzata nella sua evoluzione e nei suoi elementi. Simboli, metafore, colori che uniscono le due scritture sono passati al vaglio per meglio definire "Le Dessous des cartes" che rappresenta il punto centrale dell'attenzione dell'A., ciò che forma l'insieme delle realtà segrete, delle presenze intemporali, il modo doppio che anima la scrittura. 